\title{
Prayer and Physic in Seventeenth-Century England
}

\author{
Lauren Kassell | ORCID: 0000-0002-6415-4354 \\ Department of History and Philosophy of Science, University of Cambridge, \\ Cambridge, United Kingdom \\ ltk21@cam.ac.uk \\ Robert Ralley | ORCID: 0000-0002-9769-754X \\ Department of History and Philosophy of Science, University of Cambridge, \\ Cambridge, United Kingdom \\ robert.ralley@cantab.net
}

\begin{abstract}
Historians have often represented prayer as an instrumental response to illness. We argue instead that prayer, together with physic, was part of larger regimes to preserve health and prevent disease. We focus on early modern England, through the philosophical writings of the physician, Robert Fludd, and the medical records of the clergyman, Richard Napier. Fludd depicted health as a fortress and illness as an invasion by demons; the physician counsels the patient in maintaining and restoring moral and bodily order. Napier documented actual uses of prayer. As in Fludd's trope, through prayer, Napier and his patients enacted their aspiration for health and their commitment to a Christian order in which medicine only worked if God so willed it. Prayer, like physic, was a key part of a regime that the wise practitioner aimed to provide for his patients, and that they expected to receive from him.
\end{abstract}

\section{Keywords}

prayer - physic - regimen - therapeutics - seventeenth-century medicine - astrology medical casebooks - Robert Fludd - Richard Napier 


\section{Introduction}

Robert Fludd (1574-1637), the English physician whose elaborate images regularly adorn histories of science, depicted health as a fortress (see Fig. 1). In the centre, a man kneels in prayer, with an angel stationed at each of the four turrets defending him from the demons driven by the disease-bearing winds from the north, south, east and west. In a sister image, demons have breached one of the turrets, and a man reclines in bed, attended by a physician who feels his pulse with his left hand and inspects a flask of urine held in his right (see Fig. 2). ${ }^{1}$ Richard Napier (1559-1634), the Buckinghamshire clergyman who became a sought-after astrologer-physician, lived at the same time as Fludd though we have no indication that they knew each other. He was reputed to have spent so much time praying on behalf of his patients that his "Knees were horny." We do not know if this is entirely correct, but we do know that prayer was part of his daily regime, he prayed for some of his patients, some of them complained that they could not pray or requested that he pray on their behalf, and sometimes they prayed together. We know this from Napier's casebooks (see Fig. 3). In these, he systematically recorded thousands of consultations from the beginning of his career in the late 159os until his death three decades later. ${ }^{3}$ Fludd's works, by contrast, are theoretical. We know very little about his daily activities as a physician. This article pairs Napier's records of his and his patients' lives with Fludd's theoretical writings in order to think about medicine and religion - more specifically about prayer and physic - in seventeenthcentury England.

Traditional accounts of the relationship between religion and medicine in early modern England treated them as rival systems, setting out, within narratives of secularisation either explicit or implied, how theological explanations of disease differed from, and effectively overruled, medical teachings. Learned physicians used religious arguments, according to this view, as acts of appropriation rather than as demonstrations of belief; they employed religion to

1 William H. Huffman, Robert Fludd and the End of the Renaissance, second revised edition (London, 2018 [1988]); Ian Maclean, "Fludd, Robert," Oxford Dictionary of National Biography (2008), <www.oxforddnb.com/view/10.1093/ref:odnb/9780198614128.oo1.00o1/odnb-978 o198614128-e-9776>, accessed 9 September 2020; Luca Guariento, "Life, Friends, and Associations of Robert Fludd: A Revised Account," Journal of Early Modern Studies, 5 (2016), 9-37.

2 John Aubrey, Miscellanies upon Various Subjects (London, 1696), 133-135, at 135.

3 Major studies of Napier are Michael MacDonald, Mystical Bedlam: Madness, Anxiety and Healing in Seventeenth-Century England (Cambridge, 1981); Ronald Sawyer, "Patients, Healers and Disease in the Southeast Midlands, 1597-1634" (PhD dissertation, University of Wisconsin, 1986); Ofer Hadass, Medicine, Religion, and Magic in Early Stuart England: Richard Napier's Medical Practice (University Park, PA, 2018). 


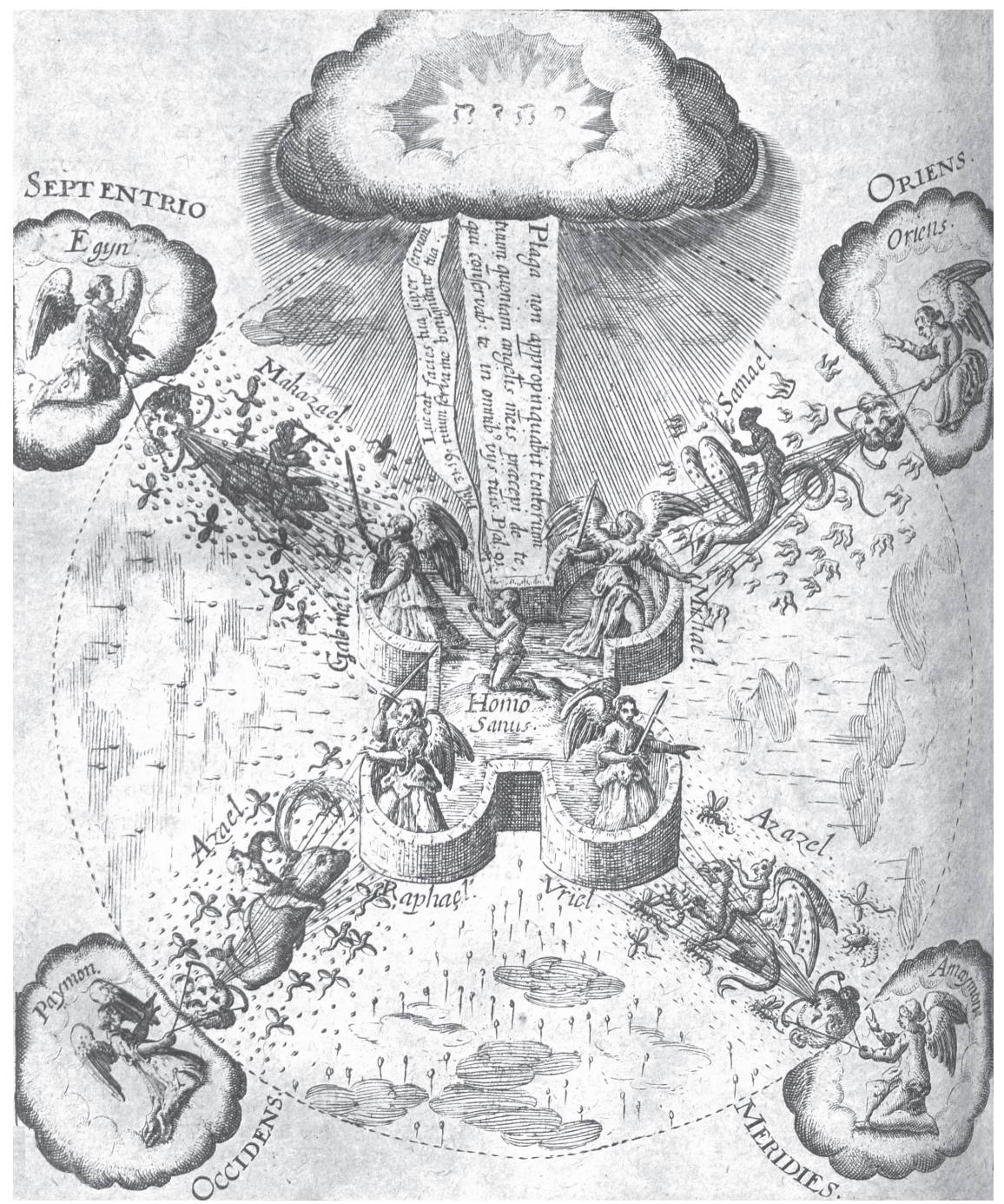

FIGURE 1 Robert Fludd, "Munimenti nostri sanitatis effigiem cum quadruplicibus dæmoniorum castris, à ventis quatuor circa illud positis" (An image of the fortress of our health with four encampments of demons placed around it by the four winds), Integrum morborum mysterium, sive, Medicinae catholicae tomi primi tractatus secundus (Frankfurt, 1631), Sectio Prima, p. 338 PUBLIC DOMAIN, DOWNLOADED FROM < HTTPS://WELLCOMECOLLECTION .ORG/WORKS/M2YKF2SK >, 27 JULY 2021 


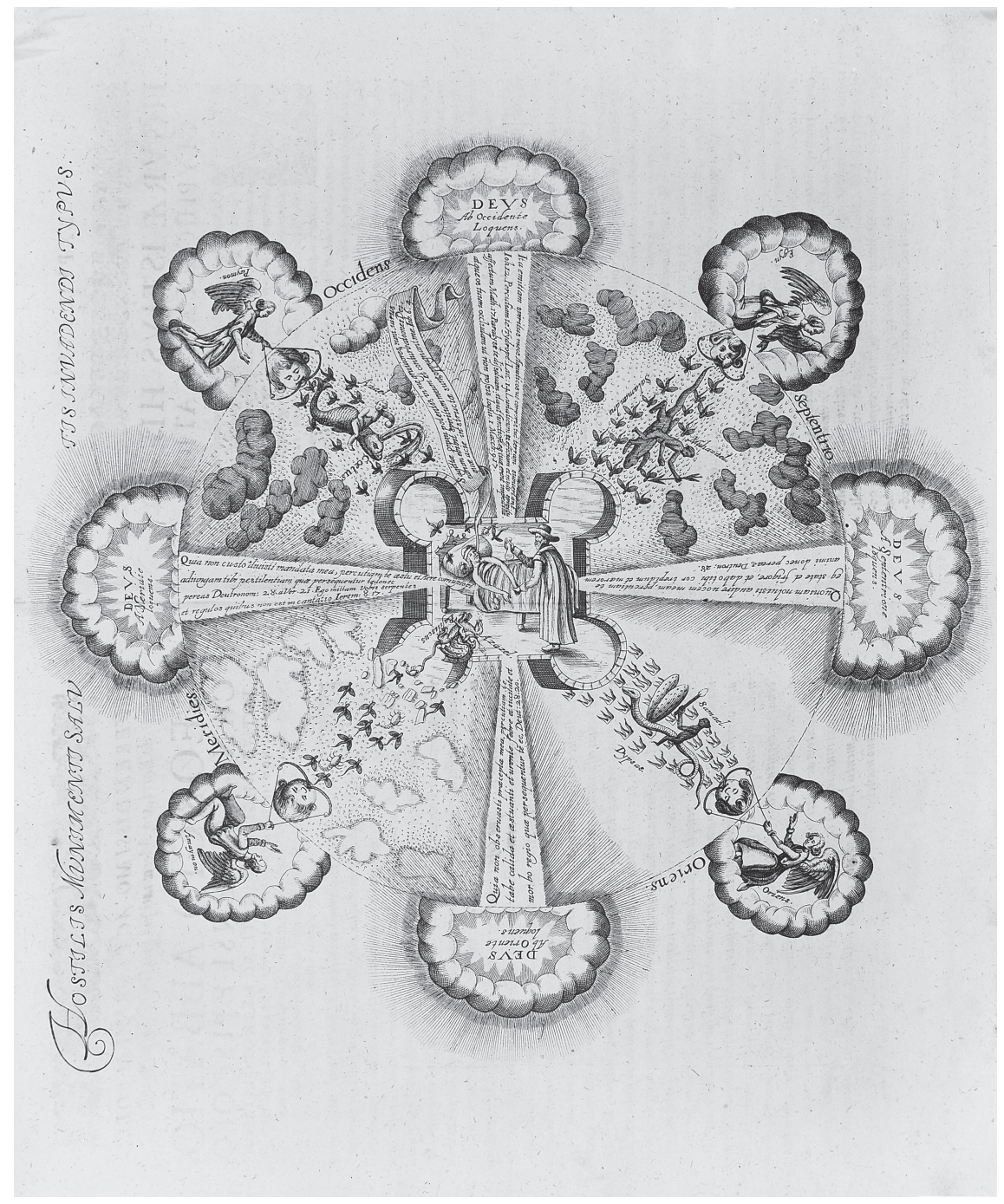

FIGURE 2 Robert Fludd, "Hostilis Munimenti Salutis invadendi typvs" (Figure of the enemy's invasion of the Fortress of Health), Integrum morborum mysterivm, sive, Medicinae catholicae tomi primi tractatus secundus (Frankfurt, 1631), [frontispiece, fol. 4] DOWNLOADED FROM < HTTPS://COMMONS.WIKIMEDIA.ORG/WIKI/ FILE:\%22THE_INVASION_OF_THE_FORTRESS_OF_HEALTH...\%22 _WELLCOME_M0011671.JPG >, 27 JULY 2021 


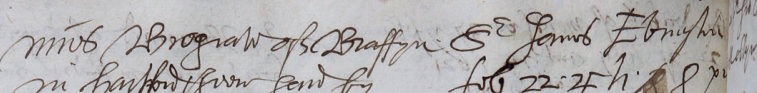

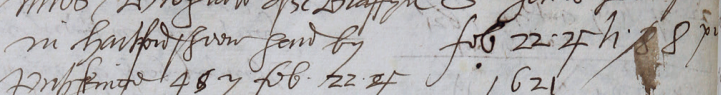

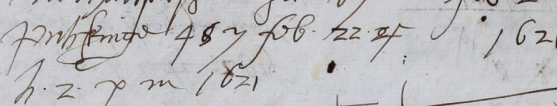

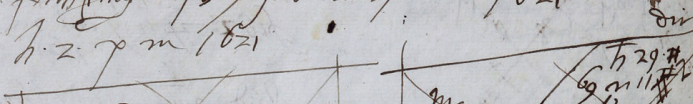

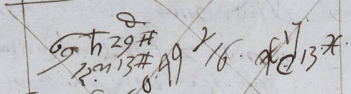
C25.0.5 40.5 .8 th

()

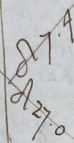

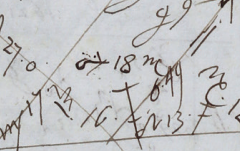

efiy a $\triangle 1$ of twar ax ov

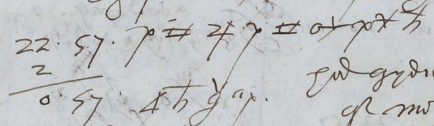

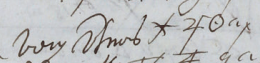
goty gormth 4 qay nomo: 4 it o dy

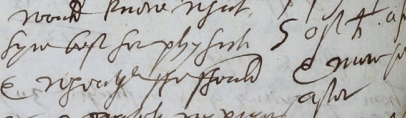
तो or $x$ thy

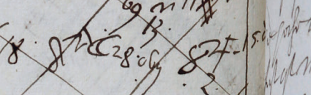

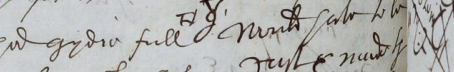
op molangoty rapt c nuw

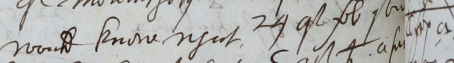

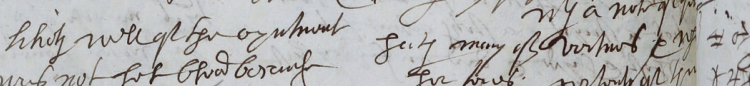

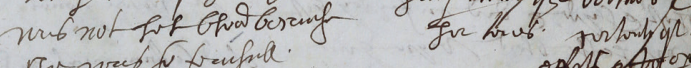
gor vour ov fangra

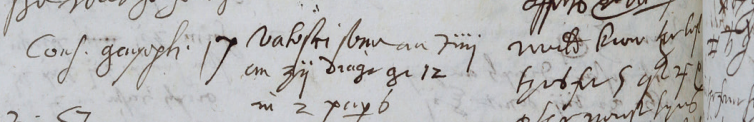

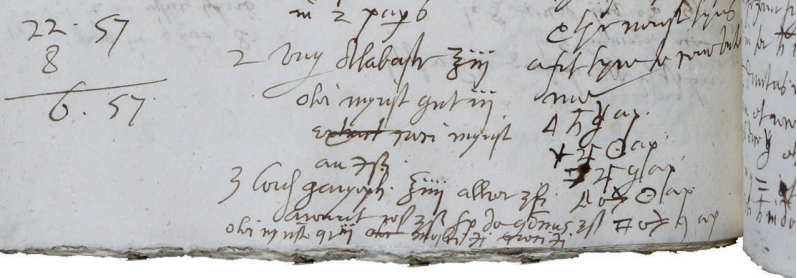

FIGURE 3 A page of Richard Napier's casebooks. Mrs Dorothy Brograve's consultation on 22 February 1621, at 2 PM (beginning on the upper left) is discussed in section 2. Kassell et al., Casebooks, CASE52066. Ms Ashmole 233, fol. $64 \mathrm{~V}$ DOWNLOADED FROM < HTTPS://CUDL.LIB.CAM .AC.UK/VIEW/MS-ASHMOLE-00233/148>, 27 JULY 2021. REPRODUCED BY PERMISSION OF THE BODLEIAN LIBRARIES, UNIVERSITY OF OXFORD 
attack competitors within the medical marketplace, and to bolster their social and economic positions. ${ }^{4}$ In contrast, other accounts explored the influence of religious beliefs and worldviews on practitioners' attitudes, and to some extent those of their patients also, towards illness and medicine. ${ }^{5}$ Some studies have sought to unpick the relationship between different doctrinal allegiances and attitudes to diseases, on the one side, and, on the other, the diseased themselves - most notably in accounts of how people who embraced forms of Calvinism approached illness and sought medical aid. ${ }^{6}$ Other studies have tied the medical philosophies that practitioners espoused to their theological convictions, as in debates over whether the medical reformers of seventeenthcentury England were driven by puritan or eirenic commitments. ${ }^{7}$ Medical practitioners, it has been made clear, acted on religious convictions even when they were criticising clergymen for providing medical ministrations to their flock; questions of who in this period should provide medical help, under what circumstances, and what treatments they should employ, were all answered in ways that invoked scripture and theology. ${ }^{8}$ The question of whether the devil was implicated in an illness was often of concern for clergymen and laypeople alike, as protestants were especially preoccupied with identifying the demonic in everyday life. Catholics, by contrast, it has been argued, accepted miracles while largely ignoring the possibility that diseases had preternatural causes. ${ }^{9}$ All of these approaches to broadly philosophical and theological questions have been met with an interest in the quotidian experiences of medical practitioners and their patients - about which we will say more below, with specific reference to prayer. Some clergymen provided medical treatments as part of

4 For example, Andrew Wear, "Religious Beliefs and Medicine in Early Modern England," in The Task of Healing: Medicine, Religion and Gender in England and the Netherlands 1450-1800, ed. Hilary Marland and Margaret Pelling (Rotterdam, 1996): 145-170, esp. 155, 159-161, 165.

5 For example, Ole Peter Grell and Andrew Cunningham, eds., Religio Medici: Medicine and Religion in Seventeenth-Century England (Aldershot, 1996).

6 David Harley, "Spiritual Physic, Providence and English Medicine 1560-1640," in Medicine and the Reformation, ed. Ole Peter Grell and Andrew Cunningham (London, 1993), 101-117.

7 Charles Webster, The Great Instauration: Science, Medicine and Reform (London, 1975); Peter Elmer, "Medicine, Religion and the Puritan Revolution," in The Medical Revolution of the Seventeenth Century, ed. Roger French and Andrew Wear (Cambridge, 1989), 10-45.

8 For example, David Harley, "James Hart of Northampton and the Calvinist Critique of Priest-Physicians: An Unpublished Polemic of the Early 162os," Medical History, 42 (1998), 362-386; Harley, "Spiritual Physic."

9 For example, Stuart Clark, "Demons and Disease: the Disenchantment of the Sick (15001700)," in Illness and Healing Alternatives in Western Europe, eds. Marijke Gijswijt-Hofstra, Hilary Marland and Hans de Waardt (London - New York, 1997), 38-55; Stuart Clark, Thinking with Demons: The Idea of Witchcraft in Early Modern Europe (Oxford, 1997); Francesco Paolo De Ceglia, "Thinking with the Saint: The Miracle of Saint Januarius of Naples and Science in Early Modern Europe," Early Science and Medicine, 19 (2014), 133-173. 
the care they offered to their flock; but this combination of medical and religious help was not restricted to men of the cloth. ${ }^{10}$ At least one physician late in the seventeenth century was offering spiritual advice to patients as part of his medical services. ${ }^{11}$

This article focuses on the spiritual writings of a physician and the medical records of a clergyman, men so devout that they never married. Fludd and Napier are regularly invoked in historical team selections as figures who looked backwards to an age when medicine was magical rather than forwards to the rise of science. ${ }^{12}$ Similarly, in grand narratives of medicalisation and secularisation, prayer is presumed to be an act of faith, physic a reasoned choice, even when allowances are made for historically specific notions of efficacy..$^{13}$ Rather, guided first by Fludd, then by Napier, we would like to suggest an approach that does not reduce prayer and physic to instrumental actions stripped of their early modern spiritual and medical meanings. The life of the body was inseparable from the fate of the soul, and Fludd's images of health as a fortress, and of illness as an invasion, are emblematic of bodily and spiritual economies. ${ }^{14}$ Similarly, in early modern England, as in pre-modern Europe more generally, medicine encompassed the maintenance of health as well as the cure of disease..$^{15}$ If health ensued from an ordered life within an ordered environment - understood as moral as well as natural - the best way to combat illness was to restore bodily purity and moral regularity. ${ }^{16}$ Prayer and physic, we argue, were part of regimes to preserve health and prevent disease.

10 Wear, "Religious Beliefs," esp. 16o-161; Harley, "James Hart of Northampton."

11 Sophie Mann, "Physic and Divinity: The Case of Dr John Downes M. D. (1627-1694)," The Seventeenth Century, 31 (2016), 451-470.

12 On science and magic, see for instance Keith Thomas, Religion and the Decline of Magic: Studies in Popular Beliefs in Sixteenth- and Seventeenth-Century England (London, 1971); Charles Webster, From Paracelsus to Newton: Magic and the Making of Modern Science (Cambridge, 1982); Stanley Jeyaraja Tambiah, Magic, Science and Religion and the Scope of Rationality (Cambridge, 1984); Euan Cameron, Enchanted Europe: Superstition, Reason and Religion, 1250-1750 (Oxford, 2010).

13 See for instance, Ian Mortimer, The Dying and The Doctors: The Medical Revolution in Seventeenth-Century England (Woodbridge, 2009), 2. On complicating narratives of healing and secularisation, see Alexandra Walsham, "Holywell: Contesting Sacred Space in Post-Reformation Wales," in Sacred Space in Early Modern Europe, ed. Will Coster and Andrew Spicer (Cambridge, 2005), 211-236, esp. 235-236.

14 Lauren Kassell, "Magic, Alchemy and the Medical Economy in Early Modern England: The Case of Robert Fludd's Magnetical Medicine," in Medicine and the Market in England and its Colonies, c. 1450-c. 1850, ed. Mark S. R. Jenner and Patrick Wallis (Basingstoke, 2007), 88-107, at 97.

15 Sandra Cavallo and Tessa Storey, Healthy Living in Renaissance Italy (Oxford, 2013).

16 Natalie Kaoukji, "Environment," in A Cultural History of Medicine in the Renaissance, ed. Elaine Leong and Claudia Stein (Bloomsbury, 2021), 23-43. 
Robert Fludd studied in Oxford in the 159os, travelled throughout Europe for five or six years, then in 1605 , at the age of 29 , he settled in London and petitioned the College of Physicians for a license to practise physic. They examined him "in both galenical and spagyrical [alchemical] medicines" but found him "not satisfactory enough in either."17 In Galenic medicine, illness was defined as an imbalance of the four humours (blood, choler/bile, melancholy, phlegm) and focused on regimen to prevent illness and treatments to evacuate the body, through bloodlettings, emetics or purges. To put it simply, alchemical medicine, as promoted by the sixteenth-century medical reformer Paracelsus and his followers, replaced the four humours with three principles (salt, sulphur, mercury) and used herbal and mineral remedies to strengthen weakened principles and clear blockages. Obviously, if it was no more complicated than this, Fludd would not have failed his examination. Eventually, in 16o8, Fludd would become a Fellow of the College and for the next thirty years he played the part expected of him in helping to promote and regulate medical practice in the city.

While Fludd was practising as a physician in London and upholding the standards of the College, he was also writing lengthy Latin books published by some of Europe's leading presses. Most assessments of Fludd conclude that he had a dual existence: by day, he worked as a London physician, part of the Galenic medical establishment; by night, he wrote Latin books, interjecting his Paracelsian, anti-Aristotelian ideas into philosophical disputes. Our view, discussed elsewhere, is that Fludd's writings and practices were aligned: in both, he was concerned to maintain the physician's mastery of the workings of nature and authority over his patients. ${ }^{18}$ Fludd's publications are as consistent as they are copious. Throughout he combines texts and emblems (what he calls "hieroglyphs") in expositions of biblical, hermetic and Neoplatonic understandings of the history of the world. These are expressed in dialogue with the conventional, university teachings grounded in Aristotelian philosophy and Galenic medicine. His two major works are Utriusque cosmi [...] historia ("History of the two worlds") (Oppenheim, 1617-1621) and Medicina catholica ("Universal medicine") (Frankfurt, 1629-1631). Utriusque cosmi [...] historia was published as five parts in two volumes, and described the analogy

17 Royal College of Physicians of London, Annals, trans. J. Emberry and S. Heathcote (unpublished typescript, 1953-1955), Book 2, pp. 175 (quotation), 181, 183, 211. Discussed in: Huffman, Robert Fludd, 33-41; Kassell, "Magic, Alchemy and the Medical Economy"; Maclean, "Fludd"; Margaret Pelling, Medical Conflicts in Early Modern London: Patronage, Physicians, and Irregular Practitioners 1550-1640 (Oxford, 2003), 28. 
between the macrocosm (the universe) and the microcosm (human life), the two worlds described in the title. Medicina catholica, published in four parts, and left unfinished, sets out Fludd's medical philosophy. To summarise, the pious physician knew that God was ultimately responsible for both medicine and disease; disease was the penalty for sin, though it might also occur in order to increase the faith of unbelievers, or sometimes for reasons known only to God. ${ }^{19}$ By means of wicked angels who control the winds, God sent bad spirits that brought disease, then "defends good [people] with his Angels, and protects those he wishes to save." ${ }^{20}$ These spirits could be "most hidden and invisibly dispersed in the air," and were what Job had called the "arrows of God."21 The air in this way made "contagious or unwholesome" was introduced into the body via its pores, and if a person was not protected by good angels, he or she would suffer humoural imbalance and disease. ${ }^{22}$ Preserving or restoring health involved attention to the non-naturals and "evacuation of superfluities and suppressing or transforming the complexion of the dangerous quality." 23

Fludd's words and images go together. He depicted the angelic defence of the body as the "Fortress of Health" (see Fig. 1) in a discussion of the causes of disease - in Fludd's terms, between the meteorological and astrological. The man kneels at the centre of the image; four angels (Michael, Gabriel, Raphael, Uriel) guard the four turrets, and all of the walls are intact. The man prays to God with a Psalm, "Make your face shine upon your servant. Keep me in your goodness."24 God responds, "No plague shall come near your tent. For I have ordered my angels over you, who will keep you in all your ways."25 Each of the angels repels a demon, blown in from the four corners of the globe. The winds, Fludd explains, embody the occult forces emanating from the celestial bodies. These forces are governed by angels and demons, and each has

19 See Robert Fludd, Integrum morborum mysterium, sive, Medicinae catholicae tomi primi tractatus secundus (Frankfurt, 1631), Sectio Prima, 477-481, for God as the final cause of disease.

"[...] bonos suis Angelis defendit, \& custodit quos preseruare volet." Fludd, Medicina Catholica, 1: 88 . “[...] spiritus istiusmodi malignus sit occultissimus, \& inuisibiliter in aere dispersus [...]," ibid.

22 “[...] contagiosum seu morbidum," ibid., 1: 101.

23 "[...] superfluorum euacuatione, \& qualitatis complexionem periclitantis suppressione seu reformatione." Fludd, Medicina Catholica, 1:230; for the discussion of non-naturals and medicines, see ibid., 1: 227-241.

24 "Fac ut luceat facies tua super servum tuum. Serva me in benignitate tua." Psalm 31.19 [sic 16], King James Version. See Fludd, Integrum morborum, Sectio Prima, 338.

25 "Plaga non appropinquabit tentorium tuum quoniam angelis meis præcepi de te, qui conservab: te in omnib[us] vijs tuis. Psal: 91." Psalm 91.10-11. Certain words differ from the usual form of this passage. 
specific properties: the northern wind is cold and dry, causing things to contract; it is countered by the warm and moist winds of the south, that dilate and dissipate. With every breath, man inhales air infused with these spirits; spirits were part of the early modern medical environment. There is a convergence in Fludd's imagination of Galenic humoural theory, Hippocratic attention to environment, Neoplatonic cosmology, and Christian devotion. So long as the forces of good and evil are evenly matched - symbolised by a man praying as he should - the walls of the fortress are not breached, and the patient remains healthy. ${ }^{26}$

If there is an invasion, as depicted in Figure 2, man takes to his bed and calls his physician. The physician adopts the pose in which he was trained (see Fig. 4). He takes the pulse and inspects the urine. Elsewhere, as we see

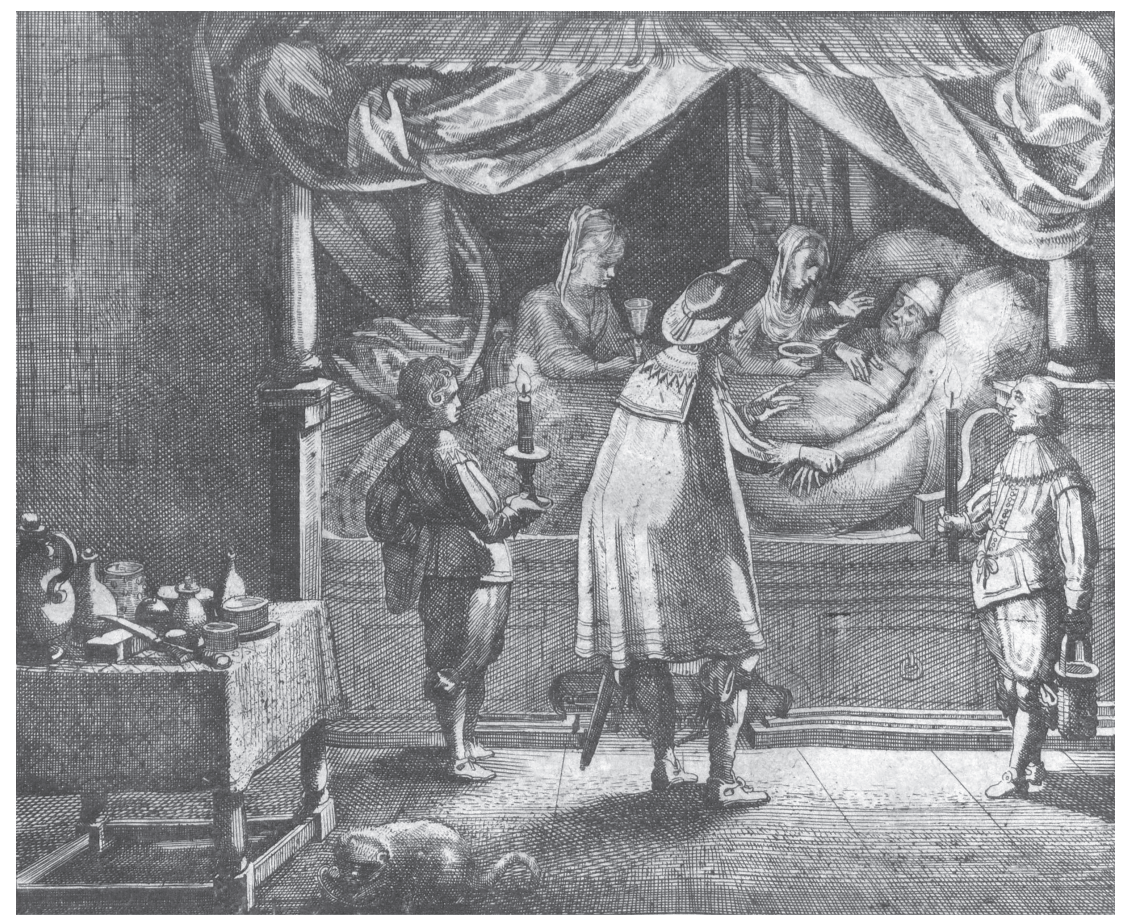

FIGURE 4 Robert Fludd, Integrum morborum mysterium, sive, Medicinae catholicae tomi primi tractatus secundus (Frankfurt, 1631), Detail of title page PUBLIC DOMAIN, DOWNLOADED FROM < HTTPS://WELLCOMECOLLECTION .ORG/WORKS/M2YKF2SK>, 27 JULY 2021

26 On the angelic, stellar and elemental causes of disease, see Fludd, Integrum morborum, Sectio Prima, 316-476; on the northern and southern winds and their effects, see ibid., 171-202. See also Robert Fludd, Mosaicall philosophy grounded upon the essentiall truth, or eternal sapience (London, 1659), 90-97, 16o-168. 
in Figure 5, Fludd represents a physician assessing a patient's urine, in what was an ancient, though increasingly contested diagnostic tool. ${ }^{27}$ In Figure 6, the physician casts an astrological horoscope, another (contested) skill of the learned physician. ${ }^{28}$ These were the tools that a physician might use to identify a humoural imbalance within the body, thus measuring which corrupting forces were causing disease. In Fludd's depiction of an invasion, the southern

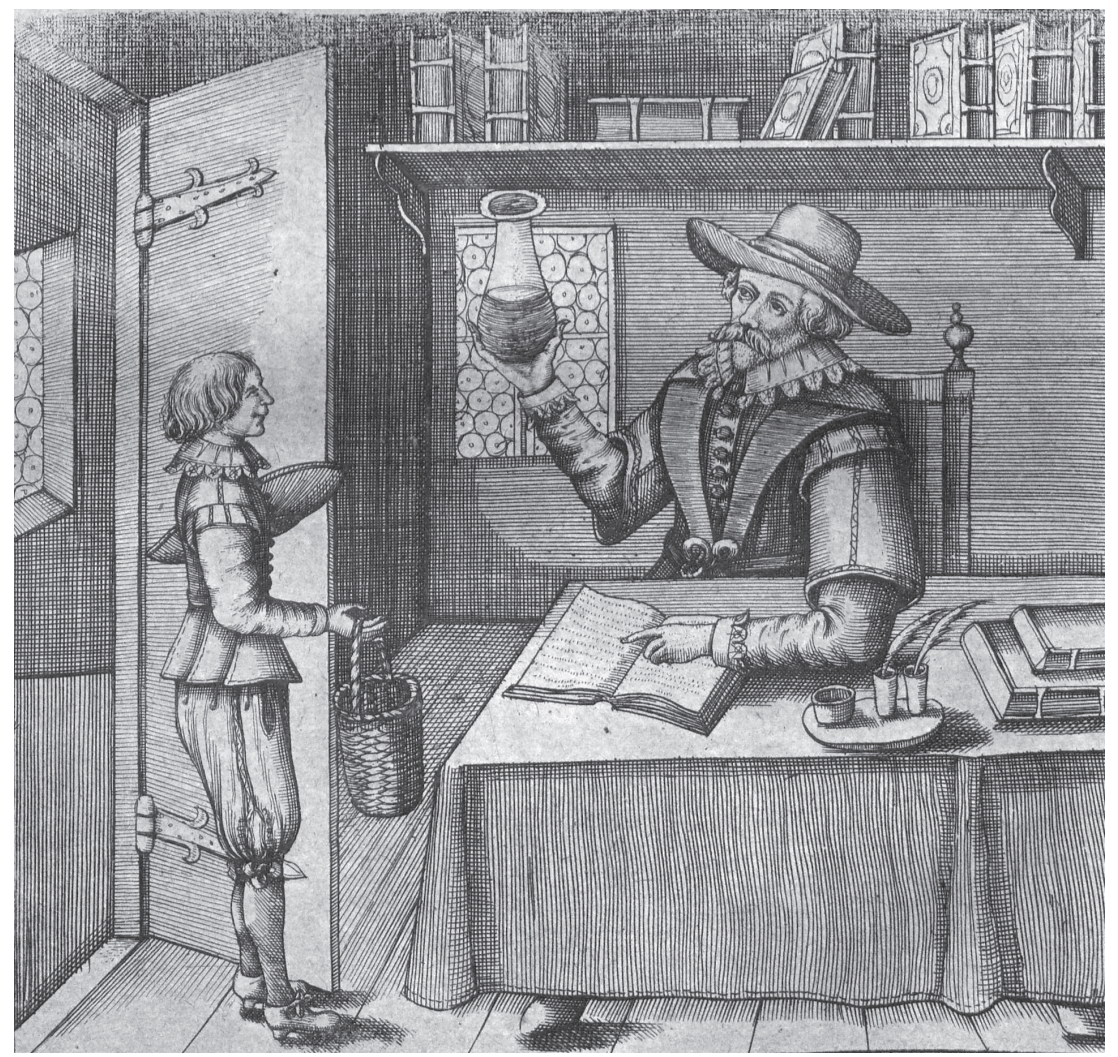

FIGURE 5 Robert Fludd, Detail of title page of "Ouromantia Physiologica, sive per urinam sedulo introspectam divinatio; in libros distributa quinque" (Physiological uromancy, or, divination by urine diligently examined; divided into five books), Integrum morborum mysteriym, sive, Medicinae catholicae tomi primi tractatus secundus (Frankfurt, 1631), Sectio Secunda, p. 255 PUBLIC DOMAIN, DOWNLOADED FROM < HTTPS://WELLCOMECOLLECTION .ORG/WORKS/M2YKF2SK>, 27 JULY 2021

27 Fludd, Integrum morborum, Sectio Secunda, 255-279; Michael Stolberg, Uroscopy in Early Modern Europe (Farnham, 2015).

28 Fludd, Integrum morborum, Sectio Secunda, 232-54. On astrology and medicine, see Michael MacDonald, "The Career of Astrological Medicine in England," in Grell and Cunningham, Religio Medici, 62-9o. 


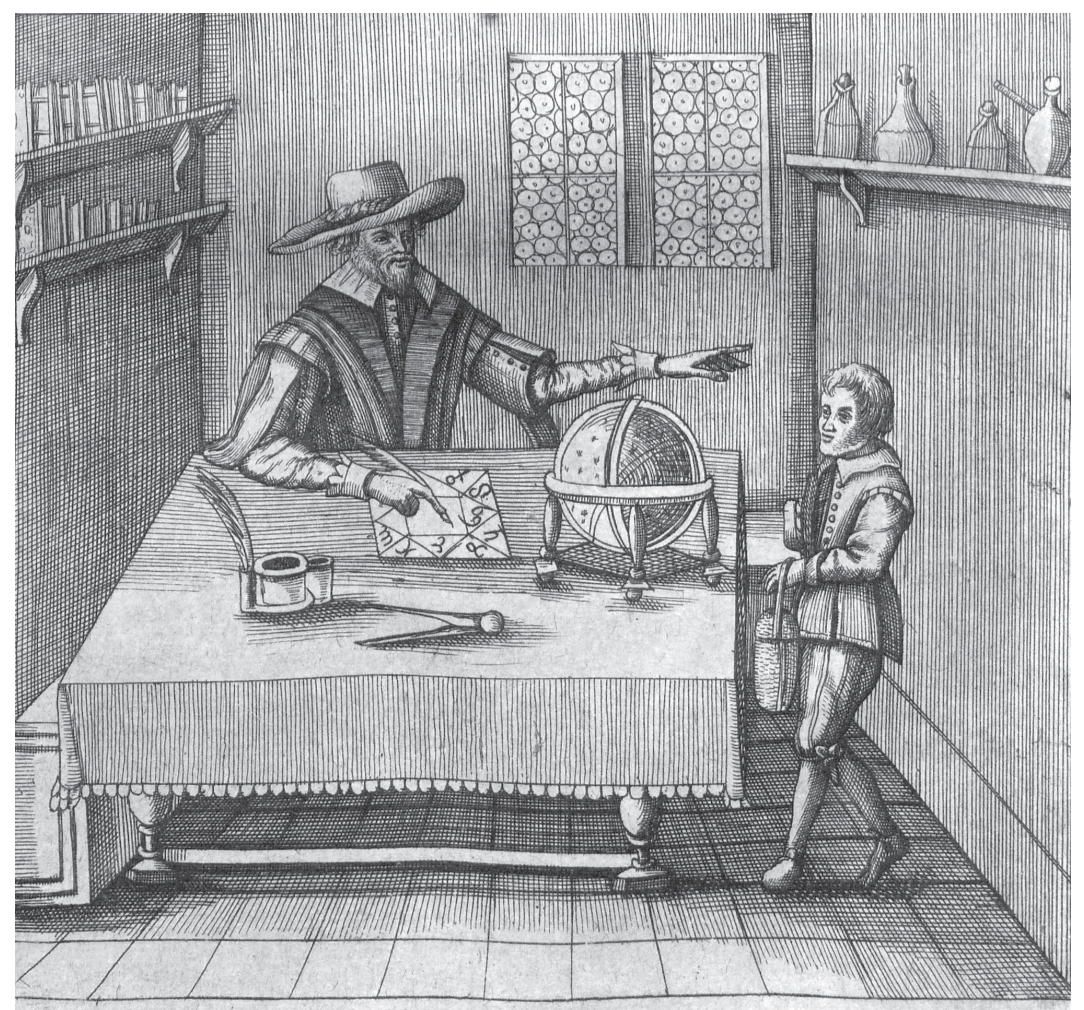

FIGURE 6 Robert Fludd, "Flud. Prognost. Supercælest." (Fludd, supercelestial prognostication), title page of "De Ouromantia iatromathematica" (On iatromathematical uromancy), Integrum morborum mysterium, sive, Medicinae catholicae tomi primi tractatus secundus (Frankfurt, 1631), Sectio Secunda, p. 233 PUBLIC DOMAIN, DOWNLOADED FROM < HTTPS://WELLCOME COLLECTION.ORG/WORKS/M2YKF2SK>, 27 JULY 2021

wall has fallen, the demon Azazael has slipped past Uriel, and the western corner is also under threat. Once he has identified the nature of the forces at work, the physician's task is to rebuild the walls and ensure that the angels return to their stations. He does this, Fludd explains, by restoring the vital spirits to man's body. These vital spirits, or forces, are expressed in terms of a balance of good and evil and humoural principles - hot, cold, moist and dry. ${ }^{29}$ Thus what Fludd called "universal" or "magnetical" medicine was compatible with humoural medicine, but distinct from it. He and his followers "judged the

29 Fludd, Mosaicall Philosophy, 55, 189, 19o, and Fludd, "A Philosophical Key," in Robert Fludd and His Philosophical Key, ed. Allen G. Debus (New York, 1979); fol. 56v, referenced here is also discussed in Huffman, Robert Fludd, 212-214. 
balance between angels and demons, redirected vital powers from dead bodies into living ones, and managed the production and disposal of bodily waste."30 This expansive medical economy endowed a physician with powers over the cosmic forces that governed health and disease. Ultimately, these ideas informed the spiritual healing of later centuries. ${ }^{31}$

The body as a fortress was a metaphor with both spiritual and physical significance. Fludd was among several medical writers of the period to emphasise the role of the skin as a line of defence: Helkiah Crooke in Mikrocosmographia (first printed in 1615), for instance, described it as "the wall of the Castle" of the body, and identified its layers as fortress defences to prevent "assault" by "the enemy."32 This description seems unremarkable to a modern eye, but was in tension with the long-standing Galenic physiology, in which the skin was notable for its porousness. Thomas Elyot's Castel of Helth, printed in numerous editions from the mid-1530s onwards, used in its title a metaphor closely related to Fludd's fortress, but in the work itself there is little reference to the body as a defensive structure; instead, Elyot described how air "doth both inclose vs, \& also enter into our bodyes, specially the most noble member, which is the hart, \& we can not be separate one howre from it"; one of the reasons why exercise benefited the body, he explained, was that "the pores of the body ar[e] more opened." 33 A far older tradition used the metaphor of the castle to stand for the individual's spiritual efforts to repel the devil. ${ }^{34}$ The thirteenth-century guide for anchoresses, the Ancrene Wisse, had used that imagery in a passage on the importance of prayer, humility and tears for keeping the devil out: a castle with a ditch around it and water in the ditch, the text explains, does not fear its enemies; and every good man that the devil attacks is a castle. With the deep ditch of humility and the water of tears, the good Christian was safe from the

$30 \quad$ Kassell, "Magic, Alchemy and the Medical Economy," 102.

31 Alex Owen, The Darkened Room: Women, Power and Spiritualism in Late Victorian England (Chicago, IL, 1989); Simon Schaffer, "The Astrological Roots of Mesmerism," Studies in History and Philosophy of Science, Part C: Studies in History and Philosophy of Biological and Biomedical Sciences, 41 (2010), 158-168; Alison Winter, Mesmerized:Powers of the Mind in Victorian Britain (Chicago, IL, 1998).

32 Helkiah Crooke, Mikrocosmographia (London, 1615), 61; Tanya Pollard, "Enclosing the Body:Tudor Conceptions of Skin," in A Companion to Tudor Literature, ed. Kent Cartwright (Oxford, 2010), 111-122.

33 Roberta D. Cornelius, The Figurative Castle: A Study in the Mediceval Allegory of the Edifice with Especial Reference to Religious Writings (Bryn Mawr, PA, 1930); quoted material from fol. 12 r; fol. $48 \mathrm{v}$.

34 Cornelius, Figurative Castle. 
devil's attacks. ${ }^{35}$ Fludd's contemporary John Donne was probably gesturing to both of these traditions when in a sermon in 1620 he glossed Job's description of the destruction of the body as "such an undermining, such a demolishing of a fort or Castle, as may justly remove us from any high valuation, or any great confidence, in that skinne, and in that body." ${ }^{36}$ Fludd's depiction of an individual assailed by demons seeking to bring disease to the body, protected by good regimen, prayer, and the help of angels, drew together these strands: the comparatively recent emergence of the metaphor of the body as a castle and the skin as its defences, keeping out those things that might harm it or bring disease; and an older motif from medieval devotional literature that envisaged the soul as a castle whose walls were protected against the devil's temptations through prayer and with the help of God.

For Fludd's contemporaries, private devotional practices, including prayers, were conducted routinely within households, as a shared experience for married couples, and spontaneously whenever an individual felt moved to do so. In diaries and letters, they documented their use of prayer to reaffirm faith and resolve doubt, as well as to ready themselves for childbirth, effect recovery from disease, or prepare for death. ${ }^{37}$ Praying was hard: as well as a gesture of body and mind, it was an act of faith. One needed to believe a prayer could work in order for it to be answered. ${ }^{38}$ Perhaps the fact that extant manuscript prayers seem seldom addressed to topics of health and medicine attests not to a dissociation between prayer and healing, but to the extent to which prayer and health were intertwined. Everyone from clergymen to grieving mothers noted the "double" effects of prayer on body and soul, and physicians explained how it worked on the vital spirits, with preventative as well as curative effects. ${ }^{39}$

Fludd's depiction of a man at prayer showed him engaged in routine devotions. The fortress and invasion are not simply a before-and-after sequence,

Robert Hasenfratz, ed., Ancrene Wisse (Kalamazoo, MI, 20oo), <https://d.lib.rochester .edu/teams/text/hasenfrantz-ancrene-wisse-part-four>, accessed 29 September 2021.

36 John Donne, "Preached at Lincolns Inne," in idem, The Sermons ofJohn Donne, ed. George Potter and Evelyn Simpson (Provo, UT, 2004-05), 15, <https://contentdm.lib.byu.edu/ digital/collection/JohnDonne/id/727>, accessed 29 September 2021.

37 Ian Green, "Varieties of Domestic Devotion in Early Modern English Protestantism," in Private and Domestic Devotion, ed. Alec Ryrie and Jessica Martin (Farnham, 2012), 9-31; Alec Ryrie, Being Protestant in Reformation Britain (Oxford, 2013), 16, 28, 41, 189, and 213, 230; Olivia Weisser, Ill Composed: Sickness, Gender, and Belief in Early Modern England (New Haven, CT, 2015). On the spiritual complexity of recovery, see Hannah Newton, Misery to Mirth: Recovery from Illness in Early Modern England (Oxford, 2018), $132 \mathrm{ff}$.

38 Weisser, Ill Composed, 67-79.

39 Sophie Mann, "A Double Care: Prayer as Therapy in Early Modern England," Social History of Medicine, 33 (2020), 1055-1076. 
with the recovering patient kneeling in supplication or gratitude. Rather, these images present the patient's prayers and the physician's ministrations as part and parcel of a Christian life. A healthy regime entailed prayer, and prayer was not, as most historians have presented it, simply a tool in the medical arsenal. Such an approach erroneously applies instrumental notions of medical efficacy to early modern understandings of illness and healing. Fludd's contemporaries did debate the therapeutic use of prayer. For instance, William Perkins, England's spokesperson for Calvinist doctrine, instructed those afflicted with sickness and disease to consult the minister first, then the physician; to pray, then take physic. Others stressed that refusing physic was a sin. Medicine was God's provision for the sick, just as food was his provision for the healthy; prayer sanctified medicine just as grace sanctified food. ${ }^{40}$ Practitioners cautioned that if a disease was caused by God, then the only effectual response was prayer; the physician should not meddle. ${ }^{41}$ In the much-publicised cases of suspected demonic possession, clergymen and physicians debated the signs of preternatural workings and the power of prayer and fasting to expel devils from within. ${ }^{42}$ These debates concerned providence and demonology, and emphasised the curative properties of prayer while saying little about its centrality to overarching regimes of maintaining and restoring health. For evidence of how prayer featured in the everyday devotional and medical practices of a physician and his patients, we will now turn to Richard Napier's casebooks.

\section{The Prayers of Richard Napier and His Patients}

Richard Napier is known to history because of his casebooks, the documents at the centre of Michael MacDonald's masterful study of madness, anxiety and healing. ${ }^{43}$ A younger son in a wealthy family, Napier studied at Exeter College at the University of Oxford from 1577 to 1586; then, in 1590, he took up a living

$40 \quad$ Ryrie, Being Protestant, esp. 127-128.

41 Harley, "Spiritual Physic"; Alexandra Walsham, Providence in Early Modern England (Oxford, 1999). Cf. Forman's remarks about a case of a sickness that comes from God and could only be cured if medicine followed prayer and repentance: Lauren Kassell, Michael Hawkins, Robert Ralley, John Young, Joanne Edge, Janet Yvonne Martin-Portugues and Natalie Kaoukji, eds., The Casebooks of Simon Forman and Richard Napier, 1596-1634: A Digital Edition, <https://casebooks.lib.cam.ac.uk/search?identifier=NOTE87>, accessed 7 September 2020. Hereafter references to case numbers and note numbers are to this site.

42 See, for instance, Marion Gibson, Possession, Puritanism and Print: Darrell, Harsnett, Shakespeare and the Elizabeth Exorcism Controversy (London, 20o6), esp. 4.

43 MacDonald, Mystical Bedlam. For works on Napier, see note 3 above. 
in Great Linford, Buckinghamshire. In 1597 he consulted Simon Forman, the famous London astrologer, about something he had lost, and, though the men were of very different characters, Napier became Forman's protégé. It was not unusual for clergymen to practise medicine, but Napier distinguished himself by becoming one of England's busiest astrologer-physicians. His practices even inspired some of the more vituperative attacks against clerical healers, on the grounds that for good Galenists and good Calvinists in the decades around 16oo, these two most dignified vocations should be distinct. ${ }^{44}$ Although such polemics fit deceptively into narratives of secularisation and medicalisation, their force for contemporaries was religious. Napier's critics suggested that by combining cures of body and soul, he was conflating, and compromising, his parochial responsibilities and medical practices.

Napier's casebooks survive from 1597 until his death in 1634 (with the exception of one missing volume), together with his other manuscript notes on theological, astrological and alchemical topics. Elias Ashmole collected Napier's papers, bound them, and bequeathed them to the Ashmolean Museum at the University of Oxford. They were moved to the Bodleian Library in 186o. Although Napier published nothing, his reputation ensured that historians of medicine, religion and magic have studied his papers, focusing on his casebooks, despite the challenges of navigating and interpreting these extensive, messy manuscripts. The work of the Casebooks Project to prepare a digital edition of Napier's casebooks has made studying them much easier. ${ }^{45}$

Napier's casebooks are diaries of his consultations, hour by hour, day by day, for four decades. As we will see, they were also diaries of his life, containing records of events including his daily devotional experiences. They are mostly in his hand, with occasional interventions by a dozen or so associates and assistants, many of whom were also his curates. Napier recorded almost 70,000 cases in which around 6o,ooo people are mentioned. For each entry, following the system of his teacher Forman, Napier began with information elicited from his clients: the patient's name, age, marital status, and - especially if consulted by message or messenger - address. Then he noted the topic of his client's questions, most of which were medical. Beneath this, Napier usually drew a horoscope that mapped the position of the stars at the time of the question or another relevant moment. Most of his consultations were "horary," meaning based on the moment that a question was asked. After considering the position of the stars, Napier recorded his judgment, drawing on his consideration of astral and other signs, including details reported by the patient or querent

44 Harley, "James Hart of Northampton"; Green, "Domestic Devotion," 27-28.

45 Kassell et al., Casebooks. 
or observed by someone else. Sometimes he consulted an angel alongside the stars; they usually replied with definite (if fallible) predictions, and occasionally suggestions for treatments. He might also record a treatment and/or a payment. The cases follow a standard format, but they vary in content and length, and often depart from the system; they were not polished documents intended for readers in the seventeenth century, or the twenty-first century. While following astrological, medical and literary conventions, and taking a form that is often fragmentary or list-like rather than narrative, Napier's casebooks provide rare evidence of early modern encounters between sufferers and healers, and of the everyday experiences, medical and otherwise, of a clergyman astrologer and his community. ${ }^{46}$

They are rich with details about prayer, ranging from drafts of prayers to the text of an exorcism; some of the prayers include specific requests, such as seeking help to "Discerne betwixt the workes of Darknes \& the workes of light." ${ }^{\prime 7}$ Mostly they are records of Napier's own prayers, or the prayers of his patients, or the lack thereof. ${ }^{48}$ Historians writing about Napier have agreed on the importance of prayer to medical practice in general, and in Napier's practice in particular. ${ }^{49}$ They have also agreed that, as Michael MacDonald puts it, Napier and other such practitioners "were chiefly concerned to discover effective medical treatments regardless of their sources." ${ }^{50}$ Historians have diverged, however, in their explanations of how prayer and treatment fitted together: was prayer just another pragmatically selected treatment, along

46 Lauren Kassell, Michael Hawkins, Robert Ralley, John Young, Joanne Edge, Janet Yvonne Martin-Portugues, and Natalie Kaoukji, eds., "Anatomy of a Case," A Critical Introduction to The Casebooks of Simon Forman and Richard Napier, 1596-1634, <https://casebooks.lib .cam.ac.uk/reading-the-casebooks/anatomy-of-a-case>, accessed 29 September 2021. For other casebooks, see Lauren Kassell, "Casebooks in Early Modern England: Medicine, Astrology and Written Records," Bulletin of the History of Medicine, 88 (2014), 595-625.

Prayers, for instance: NOTE6169; CASE42206 (Dominus Jesus conterat satanam sub pedibus suis et sub pedibus serv suorum. fiat fiat fiat); CASE20232 (Deus ista medicamenta benedicat isti materi [sic] sathannamque benedictione sua super haec medic. conterat sub pedibus). Exorcism: NOTE 978 .

48 A keyword search for "pray ${ }^{*}$ in Napier's casebooks, yields: 83 cases, 13 identified entities, 5 letters, and 91 notes (prayer is a category in the notes). See Lauren Kassell, Michael Hawkins, Robert Ralley, John Young, Joanne Edge, Janet Yvonne Martin-Portugues, and Natalie Kaoukji, eds., A Critical Introduction to The Casebooks of Simon Forman and Richard Napier, 1596-1634, search results at <https://casebooks.lib.cam.ac.uk/search?text= pray*\&sectionType $=\&$ smode $=$ simple $>$, accessed 29 September 2021 . We have augmented this with material that is not tagged in the metadata.

49 See, e.g., MacDonald, Mystical Bedlam, 220-222; Sawyer, "Patients," 127-128; Hadass, Medicine, Religion and Magic, 175, n. 182.

50 MacDonald, Mystical Bedlam, 190. 
with such therapeutics as chemical medicines and bloodletting, or did it form a more integral part of Napier's (and his patients') understanding of their illnesses, and their world more broadly?

Regardless of these differences, discussions of the role of prayer in Napier's practice have focused almost exclusively on its therapeutic effects. MacDonald suggests that Napier took participation in church ritual, including prayer, as an effective remedy where problems of the mind had arisen from "ill habits"; prayer, by implication, was part of a healthy, well-ordered routine. ${ }^{51}$ For Ronald Sawyer, in contrast, prayer was important to Napier and his patients in the same way as charms, which he glosses as "traditional sayings ... believed to be useful in curing disease." ${ }^{2}$ He points out that, outside the context of sicknesses of the mind, patients in the casebooks seldom or never mentioned God and, he concludes, they sought prayer only insofar as it was perceived to be effective. ${ }^{53}$ For Napier and his patients, Sawyer writes, "religion was another system to be pillaged in their frantic search for true healing"; prayer was worthwhile because it was held to work, not because it fitted into systems of belief. ${ }^{54}$ Accordingly, Sawyer describes their prayers as often drifting from orthodox Anglicanism to "folk formulas." 55 Like Sawyer, Ofer Hadass positions prayer within Napier's "arsenal of magical and spiritual cures." 56 However, Hadass also notes the importance of prayer in the preparation and use of sigils and in the summoning of angels; and while he notes the eclecticism of Napier's sources, practices and doctrines, he argues that Napier's was "a consistent view of religion and nature." ${ }^{57}$ In what follows, following Fludd's promptings to think of prayer as part of a regime for long-term health rather than simply as a cure for a particular disease, we will consider afresh what Napier's casebooks can tell us about the role of prayer in relation to health and illness in early modern England.

Napier prayed a lot every day, hoping for and expecting certain emotional and spiritual responses and worrying when they did not come. He kept detailed records in the casebooks of his devotional experiences. "R $\mathrm{N}$ bene affect[us] deo gr[ati]æ" (R N well affected, thanks be to God), he wrote on 22 February

$5^{1} \quad$ Ibid., $195^{-196 .}$

52 Sawyer, "Patients," 240. On charms in the context of verbal ritual, see Peter Murray Jones and Lea T. Olsan, "Performative Rituals for Conception and Childbirth in England, 900-1500," Bulletin of the History of Medicine, 89 (2015), 406-433.

54 Ibid., 239.

55 Ibid., 240.

56 Hadass, Medicine, Religion and Magic, 3.

57 For sigils, see ibid., 71, 79-80. For prayer in summoning angels, ibid., 110-113. For eclecticism, ibid., 11. For consistent worldview, ibid., 140. 


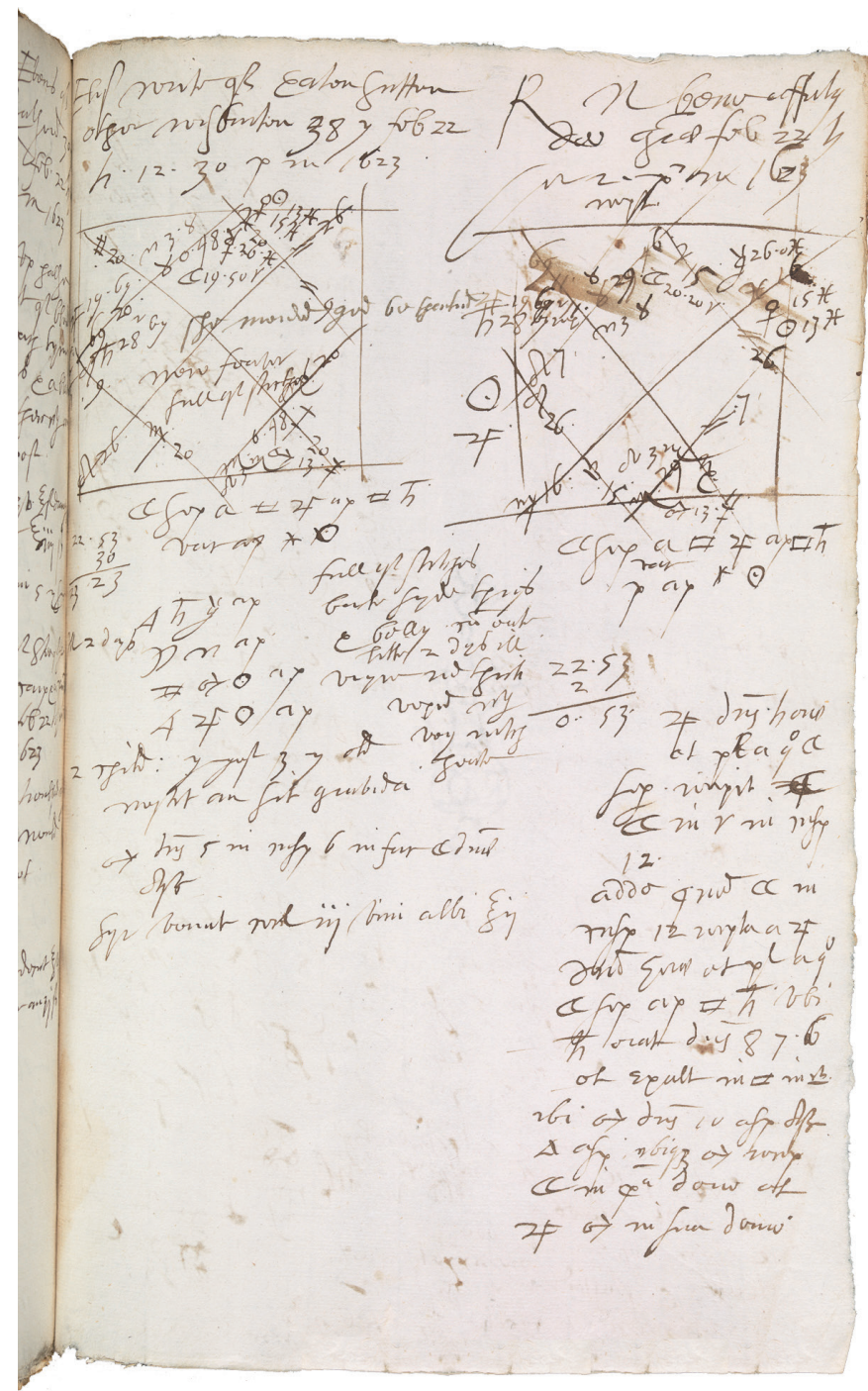

FIGURE 7 A page of Richard Napier's casebooks in which he records the date and time that his devotions moved him to tears. Kassell et al., Casebooks, CASE55631. MS Ashmole 222, fol. $176 \mathrm{r}$ (upper right) DOWNLOADED FROM < HTTPS://CUDL.LIB.CAM .AC.UK/VIEW/MS-ASHMOLE-00222/377>, 27 JULY 2021. REPRODUCED BY PERMISSION OF THE BODLEIAN LIBRARIES, UNIVERSITY OF OXFORD 
1623; "wept" (see Fig. 7).58 On more overwhelming occasions he might record "opt. aff. int[e]r pr[e]candu[m]" (excellently affected during prayer), or even "ita vt nu[n]qua[m] melius affectus" (so affected as never better). ${ }^{59}$ Tears were a familiar and desirable part of his devotions. "Int $[\mathrm{e}] \mathrm{r} \operatorname{pr}[\mathrm{e}]$ candu[m] lachrimæ effluxerunt" (tears flowed while praying) on 14 December 1627, and on the night of 7 February 1622 he wrote "p[ro]rupi int[e]r p[re]candu[m] in cæniculo fletu" (I burst into tears while praying in the upper room). ${ }^{60}$ Too much weeping could obscure his purpose, however: "in praying I was taken $\mathrm{w}^{\text {th }}$ sutch a weeping passion as I could not fynish my prayer," he noted in March $1616 .{ }^{61}$ Most dreaded were those days when he felt nothing from praying, desperately adding further prayers into his notebook entreating God not to abandon him. On 3 April 1602 he pleaded for God's mercy after recording "siccos oculos," dry eyes. ${ }^{62}$ On 25 January 1601 he wrote: "R N [...] while praying felt no devotion. May God forgive [this] humble and unworthy servant. O God, my God, may you not desert your servant, nor withdraw the spirit of grace and remorse from me. For if you forsake me, I die." 63

He then wrote that the moon was moving away from a conjunction with Mars and approaching 120 degrees from Saturn, expressing the relationship between his devotional failures and the movements of the heavens.

As an Anglican clergyman, Napier sought signs of providence in his conscience. As an astrologer-physician, he sought these signs in the stars. His teacher in astrology, Simon Forman, had listed seven "causes of mans infortune," discernible by studying a patient's astrological figure: the time of his birth, the workings of God, angels, the devil, witchcraft, his own vices, and an enemy using magic. ${ }^{64}$ If the devil or witchcraft were the cause, the cure was to "pray to god, and goe to men of arte to helpe it, or to the priest." ${ }^{65}$ Suffering

\section{CASE55631.}

59 Respectively CASE 51582 and CASE19850.

6o For 14 December 1627, see CASE65073; for 7 February 1622, see notE7449.

61 CASE42921.

62 NOTE1O325.

63 "R N. [...] int $[\mathrm{e}] \mathrm{r}$ p[re]candu[m] nulla[m] sensit devotione[m] Deus ignoscat humilli[m] o servo et indigno. O deus deus meus. ne deseras servu[m] tuu[m] nec a me auferas $\mathrm{sp}[$ irit $] \mathrm{u}[\mathrm{m}]$ gr[ati]ae et co[m]punctionis. na[m] si tu deseris perio." NOTE1487.

64 Robert Ralley, Lauren Kassell, and Michael Hawkins, eds., A Critical Edition of Simon Forman's "The Astrologicalle Judgmentes of phisick and other Questions," The Casebooks of Simon Forman and Richard Napier, 1596-1634, <https://casebooks.lib.cam.ac.uk/transcrip tions/TEXT5? show=-normalised>, ๆ996-1102. For instructions on determining which applied, see $\llbracket 1010-1017$.

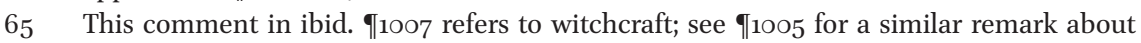
misfortune caused by the devil. 
caused by God needed more deep-rooted change, though prayer remained essential. The tenth house of the figure could be used to tell when the "finger of God" was on a patient, and whether (for instance) "the partie is loath to pray unto god for helpe," or if "the partie secketh to god for health and by prayer shall obtaine his health." ${ }^{66}$ Clear instances of Napier following Forman's instructions can be hard to find, but we have three entries from his casebooks that include the note "digitus Dei."67 It was even possible to tell in the stars, Forman believed, whether prayers were proving effective: a particular set of signs indicated that "the $\mathrm{p}[\mathrm{ar}] \mathrm{tie}$ shall be lyk to dy. yet he shall not die. for it seames good prayers $\mathrm{p}[\mathrm{re}]$ uaills $\mathrm{w}^{\text {th }}$ god. And god giueth Longer Life." 68 For Forman, the stars could show how great the need for prayer was, and whether particular prayers would succeed or fail.

In practice, things were not so simple. In Napier's casebooks, the difficulty of prayer and its proper use run through the cases of numerous patients. Some clients worried about patients who refused to pray: unwillingness to say prayers was sometimes a measure of the severity of problems of the mind. For instance, John Palmer "rageth \& will not call vppo[n] god"; Edward Bradford was "a very mad ma[n] tyed $\mathrm{w}^{\text {th }}$ chaynes," who "speaketh foolishly \& will not praye." 69 An entry for Agnes Kentish remarks that "they ca[n]not get her to say her prayers." ${ }^{70}$ Gillian Charge "thincketh prayers will doe her litle good."71 A few patients were willing but unable to pray. Melancholy prevented some, while others were thwarted by evil spirits or by the fear that they were possessed by evil spirits: Saba Beedels "p[er]suaded her selfe $\mathrm{y}^{\mathrm{t}}$ she was possessed \& then would pray mutch. \& now ca[n]not be brought to pray," and Mary Banks "fayreth as if she were haunted $\mathrm{w}^{\text {th }}$ some ill sprit $\mathrm{y}^{\mathrm{t}}$ keepeth her fro[m] praying to god." "72 Forman's astrological instructions include notes on how to determine that a patient was "much tempted and vexed," and would "pray as it seemes devoutly, but her faith faileth, and the euill spirit hath power over her and doth vexe her." ${ }^{73}$ Isabel Worly was troubled by something - whether illness or spirit is not made clear - that "tempted her at her wheele to forsake god. \& hindereth her in her prayers \& stoppeth her [...] meate in her stomacke."74

66 For the finger of God generally, see ibid., $94154-4176$; for these specific examples, see I4 4154 and $\Upsilon_{4173}$.

67 CASE19204, CASE29713 and CASE29734.

68 Forman, "Astrologicalle Judgmentes," ๆ153.

69 For John Palmer, see CASE38538; for Edward Bradford, see CASE14269.

70 CASE 37381.

71 CASE1O476.

72 For melancholy preventing prayer, see, for instance, CASE61430; CASE6og25; for Saba Beedels, see CASE 42294; for Mary Banks, see CASE38635.

73 Forman, “Astrologicalle Judgmentes," \4455.

74 CASE27354. 
Temptation could make it difficult to keep one's mind on prayer, and to mean in earnest what was being prayed: Robert Harte was tempted to give himself to the devil, and "ca[n]not pray fro $[\mathrm{m}]$ his hart"; Richard Carter was "tempted $\mathrm{y}^{\mathrm{t}}$ he ca[n]not pray."75 Judith Martin "ca[n]not pray \& is worse te[m]pted if she doe praye," while Daniel Nichols was "mutch troubled w ${ }^{\text {th }}$ evill thought in his prayers." ${ }^{\text {"7 }}$ In Napier's presence, one of his long-term patients "suddenly was taken $\mathrm{w}^{\text {th }}$ an extreme furious passionat fit" upon attempting to read the visitation of the sick from the Book of Common Prayer ${ }^{77}$ There are even occasional cases in which excessive prayer was clearly deemed a problem. In a survey of how to spot madness and frenzy in an astrological figure, Forman noted one combination of planets and constellations that "causeth a praying madnes," in which the patient "contynually prayeth," and in 1619 Napier noted that Elizabeth Steward had a troubled mind and "will pray all night longe."78 For Napier's patients and querents, as with so many others in protestant England, an impediment to timely and proper prayer could be a sign of illnesses of the body and mind, as well as an indication of interference by evil spirits.

For Napier, healing was itself a religious exercise, and he prayed for the efficacy of his treatments. In a prayer drafted twice in one of his early notebooks, he pleaded that God, who had bestowed "vertue celestiall \& power divine" on Elisa to cure Naaman of leprosy, and Moses to cure his sister Miriam, and who had given the apostles and disciples "vertue \& power [...] to heale diseases \& to cast out divels," would give him

that gift divine \& sup[er]naturall tha[t] vertue celestiall na[y] sup[er] celestiall $[\ldots] \mathrm{y}^{\mathrm{t}}[\ldots]$ whomsoever of our flock thy vnworthy shephard intendeth to heale in thy powerfull name of thy beloved sonne Ihesus. he may be healed,

and that any "vncleane spirite or spirit[es]" haunting "any of our flock" could be commanded to depart in the name of Jesus. ${ }^{79}$ In another draft, Napier explained that the "vertue \& power" given to the apostles meant "that they might heale all maner of diseases," and prayed that

|no/ disease [...] |may be soe deepely/ rooted in any lof thy servant[es] \& children/, but $\mathrm{y}^{\mathrm{t}}$ at our $\backslash \mathrm{hu}[\mathrm{m}] \mathrm{ble} /$ request \& lyernest/ suite $\backslash \mathrm{mad}$ vnto

\footnotetext{
75 For Robert Harte, see CASE6o948; for Richard Carter, see CASE51832.

76 For Judith Martin, see CASE36212; for Daniel Nichols, see CASE54123.

77 CASE569O3.

78 Forman, “Astrologicalle Judgmentes," 94736 ; for Elizabeth Steward, see CASE49208.

79 NOTE974.
} 
thy maiesty it may be removed \& the p[ar]ty diseased may be cured \& healed \& restored vnto the health of body \& minde. ${ }^{80}$

That religious framing of his medical activities extended to the compiling of his notebooks, which he frequently began with a Trinitarian formula: "Incipit liber 24 Apr. 1599. in no[m]i[n]e patris et filij et spiritus s[an]cti" (The book begins on 24 April 1599, in the name of the father and of the son and of the holy spirit), runs a typical example. ${ }^{81}$ In numerous cases, he followed up his recommended medicines with a brief note reading "Deus benedicat" (may God bless [this]). ${ }^{82} \mathrm{He}$ recorded news of successful cures with due credit to God: "by gods assist \& my physick cured," he wrote of one patient; "by gods grace cured by my means but gods spec blessing" of another; "helped by me as it pleased god," he wrote of a third. ${ }^{83} \mathrm{He}$ even observed an association between his daily prayers and his medical practice, as we can glimpse in an entry from January 1601:

At the sixth hour in the morning R. N. was unable to weep during prayers; he was touched by no devotion. It is asked what will happen today and who will consult me today. ${ }^{84}$

For Napier, there was a direct connection between the success of his prayers and his ability to heal.

Some patients asked Napier to pray for them, which might not be surprising, given that he was a clergyman; but these explicit requests for prayer appear in fewer than two dozen cases, suggesting that they are not simply evidence of the obvious overlap between Napier's medical and pastoral responsibilities. It may instead be that Napier identified clients' "craving" him to pray for them as part of the "question"; in similar fashion he faithfully recorded the questions of others who "craved to be let blood" or sent "for a purge," though the entries he then drew up were often more general and extensive than these would imply. ${ }^{85}$ One typical example of a request for prayer is Mr Uvedale, suffering from "a burning feaver," who on 26 July 1622 sent to Napier "to pray for him"; "so I

\footnotetext{
8O NOTE 975 .

81 NOTE1101. For a more elaborate example, see for instance NOTE1170.

82 See, for example, CASE19991 and CASE 32643.

83 NOTE8965; NOTE6222; NOTE2104.

84 "Int $[\mathrm{e}] \mathrm{r}$ p $[\mathrm{re}] \backslash \mathrm{c} / \mathrm{andu} \mathrm{R}$ N. |lachrimari non potuit/ [...] in aurora hora $6^{\text {ta }}[\ldots]$ nulla fuit tactus devotione quærit $[\mathrm{u}] \mathrm{r}$ quidna[m] hodie accidet $[\ldots]$ et qui quæret me hodie." CASE18767.

85 CASE31917; CASE16858.
} 
did," Napier wrote. ${ }^{86}$ Uvedale had had the fever since at least 7 March, when he had listed for Napier the treatments he had tried without success. ${ }^{87}$ On 27 July, Uvedale sent his urine and Napier detailed his problems at greater length. Feverish and costive, and fearing a consumption, Uvedale was "mutch troubled $\mathrm{w}^{\text {th }}$ melanch. $\mathrm{p}[\mathrm{er}]$ suaded of death \& will keepe bed \& not goe to chu[r]ch nor into $c 0[\mathrm{~m}]$ panye." ${ }^{88}$ In other instances, prayer appears as part of a general plea for help: on 26 October 16o9, Mrs Joan Leate, the wife of a London merchant, wrote to Napier that her daughter Denise, who had been undergoing treatment by Napier, was "mended in bodye" but amiss "in mynd." Mrs Leate "craves my help, prayers and counsel," Napier noted, though what - if any - help or counsel he gave he left unrecorded. ${ }^{89}$

A few entries more clearly record the continuing courses of treatment within which these requests for prayer appeared. In 1622, Cicely Foster, aged 43, had been ill for months with swollen legs, a swollen and painful belly, and vomiting most of what she ate; she had been bedridden for a fortnight. Napier recorded that she "desyreth but my prayers." Nonetheless, he prescribed a clyster to draw things downwards. ${ }^{90}$ Napier similarly responded with treatment when Winifred Nichols sought his prayers. She had been ill for some time, consulting Napier intermittently but with increasing frequency from the end of May 1628, when she was suffering from "a great cold" and a sore throat, a stitch, and her head was "ill," up to August and September 1629. Fear grew of a consumption and a tympany, and her husband reported that her mind was troubled. ${ }^{91} \mathrm{An}$ anxious Winifred told Napier on 25 September that not only was she "mightely hoaven \& swelled" and "very thirsty," but she "spitteth blood this day \& not before." Napier's record of her question on this day simply reads: "goody Nichols of this towne craveth my prayers." He prescribed a herbal remedy. ${ }^{92}$ Requests for prayers might indicate desperation, but in cases like these they were treated by both Napier and his patients as part of a course of treatment.

In two instances, a connection was drawn even more clearly between Napier's prayers and his astrological expertise: Dorothy Brograve and Lady Dimmock sought both his readings of the stars and his prayers. Mrs Brograve was a "very virtuous godly gentlewoman" who was "tempted to harme her selfe" and could not "endure to see a knife," troubled with both headaches and with

\begin{tabular}{ll}
\hline 86 & CASE 54688. \\
87 & CASE 53677. \\
88 & CASE 54690. \\
89 & CASE 36684. \\
90 & CASE 54239. \\
91 & For May 1628, see CASE6626; for August, see CASE69259. \\
92 & CASE6945O.
\end{tabular}


"ma $\backslash \mathrm{n} / \mathrm{y}$ feares \& greefes. not able to beare the $[\mathrm{m}] \mathrm{w}^{\text {th }}$ out the spec[ial $]$ help of god" (see Fig. 3). ${ }^{93}$ Napier prescribed her medicines and continued to suggest treatments, though her entries demonstrate a certain wariness: she "liketh well of the oyntment," Napier wrote in February, but "was not let blood because she was so fearfull." ${ }^{4}$ That April he remarked that she now "desyreth but litle physick." ${ }^{25}$ In contrast, she asked for sigils from him along with explanations of their virtues and instructions on when to take them, and she repeatedly sought prayer: on 22 December 1620, Napier judged her "desp[erate] of salvation" and noted that she "desyreth prayers above all things," and on 22 February 1621 he wrote that she "craveth my prayers." 96 Lady Dimmock, who visited Napier in London on 20 June 1624 and wrote to him for several weeks afterwards, had taken "sond $\mid \mathrm{r} /$ ye medsons [...] by the most skilfull Docters" without relief from "a mighty loosenes" that afflicted her intermittently, a fierce heat in her face and hands, swelling of her legs and other assorted pains. ${ }^{97}$ Three and a half weeks after that initial meeting, Napier reported receiving a letter saying that she had "great hope \& confidenc to receave some co[m]fort fro[m] me," and on 29 July that she was "wonderfully p[er]suaded that I shall doe her good[.] craveth my prayers \& astrolog[ical] observ[ations] in the giving of my physick." ${ }^{\prime 98}$ For Napier, and at least some of his patients, prayer and astrology were both important to the effective provision of medicine.

In a handful of instances, Napier noted that he prayed for a patient unbidden, perhaps because he sensed the work of the devil. For instance, when in 1618 Joan Kent "came to me lamenting her state telling me that she cannot resist sathan no longer," he wrote, "I prayed to god for her." 99 In 1623, seeing for the first time one of the famous Elizabeth Jennings's fits, suspected to be the result of witchcraft, he noted "I wept \& prayed for her," adding and then deleting "I prayed by her \& wept deo op. max. g[rati]ae R Nap bene affectus" (thanks [be] to God the best, the greatest, R Nap [was] well affected). ${ }^{100}$ In one of many entries for his long-time patient Emmanuel Scrope, First Earl of Sunderland,

\footnotetext{
93 Respectively: CASE52066; CASE 51338; and the last two quotations from CASE51377.

94 CASE52066.

95 CASE52333.

96 CASE52066 for sigils and her craving prayers; for December 1620, see CASE 51857 .

97 For the first meeting and reference to previous treatments, see CASE 58668 and CASE 58669; for the symptoms, see CASE 58784 .

98 For her statement of confidence, see CASE 58784 ; for 29 July, see CASE 58852 .

99 CASE 4789 o.

100 CASE57227. The fullest account of this famous case is in Kirsten C. Uszkalo, Being Bewitched: A True Tale of Madness, Witchcraft, and Property Development Gone Wrong, (Kirksville, MO, 2017).
} 
Napier himself asked the question and recorded prescribing various syrups and lozenges, and, noting the specific time, wrote "I prayed for him."101

Despite his reputation for praying with his patients, we have found very few records of such habits. He recorded having done so in two entries. The first was on 3 June 1629, when Henry Pickering was brought to him. It was Pickering's third question, and at least his second visit, in under a week: he was "senceles \& mopish," Napier had written the previous day, and had "no vse of his wits \& sences"; his mind was troubled "for love to a wench $\mathrm{y}^{\mathrm{t}}$ sckornd him." ${ }^{102}$ Napier reported that Pickering "talketh mutch \& co[n]tinually but he knoweth not what he sayth nor what he doth." ${ }^{103}$ On this occasion, Pickering "was brought to me agayne \& we prayed togeath ${ }^{r}$."104 That November, Napier drew up an astrological chart for the moment on the morning of the 21st at which a residential patient, Lady Hanmer, "came to my study wher we prayed at this tyme." According to Napier's earlier notes, Lady Hanmer had been "melanch: all her life tyme," and had become distressed in her mind after hearing of the judgments of God in a sermon. ${ }^{105}$ Hanmer, from Flintshire in Wales, seems to have been staying locally for her treatment. ${ }^{106}$ On the day when Napier recorded praying with her, her urine was "a filthy troubled water" and she could "eate litle." He prescribed medicines and bloodletting. It is worth repeating, however, that praying could be hard. On 6 July 1625, a Mr Harris came to pray with Napier, but when Napier began he found he "was still hinde[red] \& letted $\mathrm{y}^{\mathrm{t}}$ I cou[ld] not fynish it for co[m]p[any]."107

We glimpse some details of these prayers: Jane Ringe, for example, was disquieted in mind, having buried a child, and Napier wrote out a prayer, perhaps to say with her or to give to her to take away: "Lord Jesus comfort and strengthen her faith and mightily defend her against ghostly enemies."108

101 CASE70745. Also: CASE22611, 1630, Napier asked about Sir John Underhill and noted, "Sir John und. \& Mr Kirkland \& my selfe prayed for Sir John." NOTE7888, 1623, Napier went and prayed by Sir Thomas Compton, who was mopish, refused to eat and talked childishly.

102 For the description of him as senseless, see CASE68863; for the reference to lovesickness, See CASE68831.

103 CASE68863.

104 CASE68868.

105 For her lifelong melancholy, see CASE69573; for the effect of the sermon, see CASE69349.

106 Four days earlier, she and Napier had been visited by a relative of hers (CASE69576), and on 1 January she sent Napier a New Year's gift of $£_{5}$ in gold, while he in turn sent money to her servant and her waiting gentlewoman (NOTE9480, in which Napier incorrectly gives the date as 1629).

107 NOTE 8394.

108 CASE12389; see also MacDonald, Mystical Bedlam, 222. 
Conversely, when Alice Emmerton was troubled in mind because God had sent her an unwanted extra child, Napier wrote "god co[m]forte \& establish her mynd \& harte" at the end of the entry. ${ }^{109}$ His casebooks contain numerous such short prayers, in English and Latin, on behalf of patients and for himself. On occasion he recorded having recited or suggested set prayers, on another he lent a patient his Book of Common Prayer, and at various times he appears to have drafted prayers of his own. ${ }^{110}$ With these various sorts of prayers, there is little indication that either Napier or his patients expected automatic results or saw them as anything other than prayers for God's help. ${ }^{111}$

Prayer was a means of communicating with God. It was also, though Napier was seldom explicit about this, his means of communicating with angels. ${ }^{112}$ The angels in Fludd's emblematic images were real beings, usually invisible, but ever-present, and open to representations from people with exceptional purity of body and soul - like Fludd and Napier. ${ }^{113}$ One surviving formula in Napier's papers illustrates the sort of prayer he used:

Lord I beseach thee to give these thy good $\backslash \&$ holy $[\ldots] /$ angels leave \& power to mynister to the $\mathrm{p}[\mathrm{ar}]$ ties helpe $[\ldots]$ succour \& ease to $[\ldots]$ beate downe sathan vnder there feete to confound him with all $\backslash$ his/ sorcery inchantment \& witchery \& to voyd all \his wicked \& evill/ tentations \& to banish \& drive away all fond $\mid \&$ false/ visions $\mid \&$ Dremes/ foolish \& wicked illusions wherew ${ }^{\text {th }}$ any of $\backslash$ these/ thy $\backslash$ forenamed/ creatures have bene haunted vexed troubled \& disquieted. ${ }^{114}$

\section{CASE16994.}

110 For instances of reading set prayers, see, e.g., CASE56903; for his recommending prayers (to the same patient), see NOTE7976; for lending the Book of Common Prayer, see NOTE9825. For examples of prayers drafted by him, see above (for example, the prayer for healing powers).

111 He also noted a very small number of treatments based around verbal formulae, presumably copied from other sources (see, e.g., NOTE2114 and NOTE3765). However, he rarely if ever recorded using them; most of the few examples in the casebooks are not in Napier's own hand, and CASE35312, an example written by Napier, is a question by Forman about Forman's son (and may therefore have been copied from a lost volume of Forman's). These formulae typically do not resemble prayers.

112 Hadass, Medicine, Religion and Magic, 86-122.

113 Peter Marshall and Alexandra Walsham, eds., Angels in the Early Modern World (Cambridge, 20o6); Joad Raymond, ed., Conversations with Angels: Essays Towards a History of Spiritual Communication, 1100-1700 (London, 2011).

114 NOTE5722. 
Angels appear 1,125 times in Napier's casebooks, mostly in 1611 and 1612, with up to several dozen a year through 1620 and none after 1626 . The angels helped him with judgments (she's pregnant) and remedies (give her a purge). Napier also compiled lists of things to ask the angels, again with questions about judgments and remedies. Here we find notes such as "an effectuall prayer to cure diseases," and "A prayer for sutch as are deadly sick to recoav ${ }^{r}$ the[m]. if they be to be recoavered \& to co[m] fort \& to strenthen there harte \& fayth." ${ }^{\prime 15}$ Or more elaborately, in October 1611, the angel Raphael (denoted by R) instructed Napier in how to make a tin sigil:

this litle white sigill of tyn $\mathrm{y}^{\mathrm{t}}$ hath the pl[anet] 2 \& his charects is good for many infirmityes. for all maner of diseases for falling sicknes, gout Dropsyes apoplexies. stone cholick. or any other disease whatsoev ${ }^{r}$. curable or incurable $\mathrm{w}^{\text {th }}$ good prayer \& [...] also agaynst all evill sprites ferys witcheryes possessed. frentick lunatick to sigillate any trochiske [medicinal tablet] at any time or for any person given steped in drinke or wyne or milke or in losenges. Bx Octob 17. h. 430 PM 1611. it helpeth at twice giving[.] ${ }^{116}$

Through prayer, Napier communicated with angels, and angels in turn advised him on the prayers that he should recommend to his patients. A wise physician could supply his patients with prayers to cure disease and promote faith.

\section{Conclusion}

Napier's casebooks help us see both the difficulty and the necessity of prayer in early modern England. As an activity involving the mind, it was bound up with the passions, understood as affective responses tied to bodily manifestations. Napier hoped that his prayers would produce in him the right emotions, and many clients consulted him because somatic and spiritual problems were hindering them from praying. Prayer was an essential part of Napier's medical practice in general, and it featured in particular healing processes. He prayed for healing powers, for advice, and for the health of his patients; some clients came to him specifically for his prayers. No treatment, no matter what it involved, was credited alone with curing a patient: Napier believed that God's help was essential to any successful cure. Prayers, for Napier and his patients, played a

115 For "An effectuall prayer [...]," see NOTE7586; for "A prayer for sutch [...]," see NOTE7582. 116 NOTE5231. 
crucial role in health and healing. They were not used solely to return pious order to the lives of people with religious worries; they were of more fundamental importance than that. They were not simply verbal formulae whose meaning was irrelevant provided they achieved the desired effect. In a basic sense they were not treatments at all. Just like the devout figure in Fludd's Fortress of Health, through prayer, Napier and his patients enacted their aspiration for health and commitment to a Christian order in which medicine only worked if God so willed it. Prayer, like physic, was a key part of a regime of health and healing that the wise practitioner aimed to provide for his patients, and that they, in turn, expected to receive from him.

\section{Acknowledgments}

This article began as a keynote lecture for "Angelical Conjunctions: Crossroads of Medicine and Religion, 1200-180o," organised by Aslıhan Gürbüzel and Faith Wallis at the McGill Institute of Islamic Studies and Department of History and Classical Studies, Montreal, 12-14 April 2019. We are grateful to them, and all of the participants of the conference, for prompting us to think more thoroughly about this topic. We are also grateful to the astute questions about an earlier draft of the article posed by members of the Early Science and Medicine Work-in-Progress Group at the Department of History and Philosophy of Science, University of Cambridge. Our research on Napier's casebooks was supported by Wellcome Trust Programme Grant o9o619, and Wellcome Trust Strategic Award 104083. 